\title{
Community ecology of metazoan parasites of the sairú Cyphocharax nagelii from the Peixe River
}

\author{
Ecologia da comunidade de metazoários parasitos do sairú Cyphocharax nagelii do Rio do Peixe
}

Diego Henrique Mirandola Dias Vieira ${ }^{1}$; Luhan Eduardo Caramello'; Vanessa Doro Abadallah²; Reinaldo José da Silva'; Rodney Kozlowiski de Azevedo ${ }^{2 *}$

${ }^{1}$ Departamento de Parasitologia, Instituto de Biociências, Universidade Estadual Paulista - UNESP, Botucatu, São Paulo, Brasil ${ }^{2}$ Universidade Sagrado Coração - USC, Bauru, SP, Brasil

Received April 24, 2013

Accepted October 11, 2013

\begin{abstract}
A total of 57 sairus (Cyphocharax nagelii) from the Peixe River, state of São Paulo, southeastern Brazil, were examined between April 2011 and February 2012. Eleven species of metazoan parasites were collected and identified: Palombitrema triangulum, Curvianchoratus hexacleidus, Curvianchoratus singularis, Sphincterodiplostomum musculosum, Contracaecum sp., Cacatuocotyle paranaensis, Cosmoxynemoides aguirrei, Amplexibranchius bryconis, Brasergasilus sp., Ergasilus sp. and Clinostomum sp. The monogenean P. triangulum was the most prevalent species (61.40\%) with the highest mean intensity (4.88). The monogeneans $C$. hexacleidus and $C$. singularis, the digenean $S$. musculosum and the nematode Contracaecum sp. also showed high prevalence. Only $S$. musculosum presented significant correlation between the total body weight of the host and its abundance. The parasitic infracommunities had a mean Brillouin diversity $(H B)$ of $1.165 \pm 0.987$ and the maximum diversity was 1.671 . The sex and length of the hosts did not influence the abundance of any parasite species. The community of metazoans in $C$. nagelii from the Peixe River was characterized by high richness and low uniformity.
\end{abstract}

Keywords: Fish, Curimatidae, parasites, Peixe River, Brazil.

\section{Resumo}

Cinquenta e sete "sairú" (Cyphocharax nagelii) foram examinados entre abril de 2011 e fevereiro de 2012, provenientes do Rio do Peixe, Estado de São Paulo, Sudeste do Brasil. Onze espécies de metazoários parasitos foram coletadas e identificadas: Palombitrema triangulum, Curvianchoratus hexacleidus, Curvianchoratus singularis, Sphincterodiplostomum musculosum, Contracaecum sp., Cacatuocotyle paranaensis, Cosmoxynemoides aguirrei, Amplexibranchius bryconis, Brasergasilus sp., Ergasilus sp., Clinostomum sp. O monogenético P. triangulum foi o parasito mais prevalente $(61,40 \%)$ e com a maior intensidade média $(4,88)$. Os monogenéticos $C$. hexacleidus e $C$. singularis, o digenético $S$. musculosum e o nematóide Contracaecum sp. também apresentaram alta prevalência. Apenas $S$. musculosum apresentou correlação significativa entre o peso total do corpo do hospedeiro e sua abundância. As infracomunidades parasitárias tiveram uma diversidade média de Brillouin $(H B)=1,165 \pm 0,987$ e a diversidade máxima foi de 1,671. O sexo e comprimento dos hospedeiros não influenciaram a abundância parasitária. A comunidade de metazoários de $C$. nagelii no Rio do Peixe foi caracterizada pela alta riqueza e baixa uniformidade.

Palavras-chaves: Peixe, Curimatidae, parasitos, Rio do Peixe, Brasil.

Cyphocharax nagelii (Steindachner, 1881), known locally as the sairú, is a Curimatidae with geographical distribution restricted to South America, and is found especially in the upper Paraná River basin. The species is involved in large seasonal migration from the Mogi Guaçu River, an upper Paraná River tributary. Young fish aged up to 50 days were reported as being zooplanktivorous,

\footnotetext{
${ }^{*}$ Corresponding author: Rodney Kozlowiski de Azevedo

R. Irmã Arminda, 10050, Vila Brunhari, CEP 17011-160, Bauru, SP, Brasil

e-mail: azevedork@hotmail.com
}

and the larger ones as detritivorous. This species reaches maturity at around the length of 8.9 centimeters for both sexes, and can reach a maximum length of $16.3 \mathrm{~cm}$ (VARI, 1992).

The Peixe River begins in the municipality of Torre de Pedra, state of São Paulo, in the basaltic cuesta of the Botucatu Environmental Preservation Area and it is a drainage basin comprising 584 $\mathrm{km}^{2}$ that runs from north to south (CARAMASCHI, 1986). According to Caramaschi (1986), the physiographic and landscape characteristics vary: some areas present primary vegetation on the 
mountainside of the cuesta and some stretches present gallery forests among pastures and small-scale farming. There are several ecosystems next to dams that interface with the main river. Besides the gallery forest stretches, there are many marginal lagoons that present mosaics of aquatic macrophytes that are connected to the river under natural and anthropic hydrological regimes (controlled by the Barra Bonita hydroelectric power plant). In addition, over a large extent of its surroundings, there are human settlements of increasing size (recreational farms and ranches for both sport and artisanal fishing), intensive agricultural activities (especially sugar cane) and cattle-raising activities (NOVAES, 2008). There are many species of fish in this river, including the species Cyphocharax nagelii (Steindachner, 1881).

Few studies have been conducted on Cyphocharax nagelii metazoan parasites in Brazil, but this same host is called Curimata nagelii and Pseudocurimata plumbea in other parasitological papers. Among these records, it is important to highlight the following: Abdallah et al. (2012), Kohn et al. (2011) and Pavanelli et al. (2000) for nematodes; Kohn and Fernandes (1987) and Kohn et al. (2011) for digeneans; Pavanelli et al. (2000) for crustaceans; and Martins and Onaka (2006) for the myxozoan species Henneguya garavelli and Myxobolus peculiaris in the Peixe River.

The present paper had the aim of presenting a qualitative and quantitative analysis on the structure of the Cyphocharax nagelii parasite community of the Peixe River, because of the strategic importance of this river for the region. Moreover, good knowledge of parasite diversity is crucial for environmental management and conservation.

Fifty-seven specimens of $C$. nagelii were collected from the Peixe River ( $22^{\circ} 49^{\prime} 53.1^{\prime \prime} \mathrm{S}$ and $\left.48^{\circ} 06^{\prime} 38^{\prime \prime} \mathrm{W}\right)$ in the municipality of Anhembi, state of São Paulo, Brazil. The fish were collected between April 2011 and February 2012. Immediately after being caught, the specimens were killed by transection of the spinal cord. The mean total length of the female specimens was
$12.9 \pm 3.1(8.9-15.3) \mathrm{cm}$ and the mean weight was $64.2 \pm 10.4$ $(17.9-103) \mathrm{g}$. The mean total length of the male specimens was $14.1 \pm 2.4(9.4-17.8) \mathrm{cm}$ and the mean weight was $67.3 \pm 13.6$ (19.6-108) g. Parasite prevalence, intensity and abundance were calculated as prescribed by Bush et al. (1997). Parasites were classified according to their prevalence in the core species (prevalence higher than 66.66\%), secondary species (prevalence from 33.33 to $66.66 \%$ ) and satellite species (prevalence lower than 33.33\%) to verify the importance value of each species in the helminth parasite community (BUSH; HOLMES, 1986). The variance of the mean ratio of parasite abundance (dispersion index) was used to determine spatial distribution patterns and was tested by means of the $d$ statistical index (LUDWIG; REYNOLDS, 1988). The frequency dominance and relative dominance (number of specimens of one species/total number of specimens of all species in the infracommunity) of each parasite species were calculated in accordance with Rohde et al. (1995). Spearman's rank correlation coefficient $(r s)$ was calculated to determine possible correlations between the host's total body length and the abundance of parasites, and between the host's total weight and the abundance of parasites (ZAR, 1999). The analysis only included parasite species with prevalence greater than 10\% (BUSH et al., 1990). The following community descriptors were calculated at the infracommunity level: Brillouin's diversity index ( $\log 10$ based), Pielou's evenness index, Margalef's richness index and the Berger-Parker dominance index. The statistical significance level was established as $\mathrm{p}<0.05$. The ecological terminology followed Bush et al. (1997). Voucher specimens of the helminths were deposited in the Helminthological Collection of the Institute of Biosciences, Botucatu (CHIBB), in the state of São Paulo, Brazil.

Component community. Eleven metazoan parasite species were collected (Table 1). Most of the parasite species collected were monogenetic $(62.26 \%)$, followed by nematodes $(20.59 \%)$, digenetic $(13.56 \%)$ and crustaceans (3.56\%). Palombitrema triangulum was

Table 1. Prevalence, mean abundance, mean intensity and infection site of the metazoan parasites of Cyphocharax nagelii (Steindachner, 1881) in the Peixe River, state of São Paulo, Brazil.

\begin{tabular}{|c|c|c|c|c|c|}
\hline Parasites & Prevalence (\%) & Mean abundance & Mean intensity & Infection/infestation site & $\begin{array}{c}\text { Species } \\
\text { importance }^{\mathrm{a}}\end{array}$ \\
\hline \multicolumn{6}{|l|}{ Crustacea } \\
\hline Amplexibranchius bryconis & 14.03 & 0.33 & 2.37 & Gills and body surface & Sa \\
\hline Ergasilus sp. & 1.75 & 0.03 & 2 & Gills & Sa \\
\hline Brasergasilus sp. & 1.75 & 0.01 & 1 & Gills & Sa \\
\hline \multicolumn{6}{|l|}{ Digenea } \\
\hline Sphincterodiplostomum musculosum & 42.1 & 1.43 & 3.41 & Eyes & Se \\
\hline Clinostomum sp. & 1.75 & 0.01 & 1 & Eyes & $\mathrm{Sa}$ \\
\hline \multicolumn{6}{|l|}{ Nematoda } \\
\hline Cosmoxynemoides aguirrei & 15.78 & 0.59 & 3.77 & Intestine & Sa \\
\hline Contracaecum sp. & 36.84 & 1.61 & 4.38 & Intestine and stomach & $\mathrm{Se}$ \\
\hline \multicolumn{6}{|l|}{ Monogenea } \\
\hline Cacatuocotyle paranaensis & 21.05 & 1.05 & 5 & Nostril & Sa \\
\hline Curvianchoratus hexacleidus & 42.1 & 0.82 & 1.95 & Body surface & Se \\
\hline Curvianchoratus singularis & 54.38 & 1.8 & 3.21 & Body surface & $\mathrm{Se}$ \\
\hline Palombitrema triangulum & 61.4 & 3 & 4.88 & Body surface & $\mathrm{Se}$ \\
\hline
\end{tabular}

aSpecies importance based on prevalence: Se, secondary species (prevalence from 33.33 to 66.66\%); Sa, satellite species (prevalence lower than 33.33\%). 
the predominant species, with 171 specimens collected $(27.95 \%$ of the total parasites), presenting the highest value for dominance frequency (Table 2). The parasites presented the typical aggregated distribution pattern (Table 3). The species Sphincterodiplostomum musculosum presented a significant correlation between host body total weight and parasite abundance ( $r s=-0.28, \mathrm{P}=0.03$ ), while the other species did not present any significant correlation.

The effect of the sex and length of the hosts and the abundance of the parasites did not present any significant difference. Sphincterodiplostomum musculosum, Contracaecum sp., Curvianchoratus hexacleidus, Curvianchoratus singularis and Palombitrema triangulum were the secondary species and the remaining ones were considered to be satellite species (Table 1).

Infracommunities. Fifty out of the 57 specimens of $C$. nagelii examined were parasitized by at least one metazoan species. A total of 612 parasite specimens were collected with a mean of 10.74 parasites per fish. Seven hosts (12.28\%) were not parasitized by any metazoan parasite species; ten $(17.54 \%)$ were parasitized by one species, eight $(14.04 \%)$ were parasitized by two species, eight $(14.04 \%)$ were parasitized by three species, ten $(17.54 \%)$ were parasitized by four species, eight $(14.04 \%)$ were parasitized by five species, five $(8.77 \%)$ were parasitized by six species and one $(1.75 \%)$ was parasitized by seven species. The effect of the sex and length of the hosts and parasite abundance did not present statistically significant results. The mean parasite richness index was $d=2.402$ and the Pielou uniformity mean index was $\mathrm{J}=0.463$. The parasite infracommunities presented mean diversity of $H B=1.165 \pm 0.987$ and maximum diversity of 1.671. No significant correlation was detected between the diversity of parasite species and the sex, total length and weight of the hosts. The Berger-Parker dominance index presented a mean of $0.51 \pm 0.30$.

The results from this study indicate that the metazoan community of $C$. nagelii has high diversity due to high species richness, despite the great variability in species abundance. According to Bush et al. (1997), diversity is the concept that describes the composition of a community regarding the number of species and some factor that measures the relative equality of the distribution of each species. There is no environment where all of the species are equally common. Some are very abundant, others are moderately common, and most are rare. Biodiversity can be split in two components: species richness and uniformity (equitability). In these, species richness is the number of species in a sample and uniformity describes the variability in the abundance of species. A community is considered rather uniform when all the species contain approximately the same number of individuals, whereas a wide disparity in the relative abundance of species results in low uniformity (MAGURRAN, 1988). Pielou (1977) commented that communities with high richness of species, high uniformity or both are generally considered to be more diverse.

The host length, which is considered to be an expression of its age, is one of the most important factors in the variation in the size of the parasite infracommunities. Age causes several changes to fish biology, especially in relation to trophic levels, which are directly reflected in the parasite fauna, particularly for parasites acquired through food chain, as mentioned by Dogiel et al. (1961). In the present study, the length did not have any positive correlation with any species, and this may have been due to the small amplitude of the host length since all of the specimens studied were adults and there was no change in the fish feeding. Although the sex of the host has an essential role in the host-parasite relationship, it had no influence on the $C$. nagelii parasitism rate in the present study. This may suggest that the ecological relationships (habitat, behavior and diet) between male and female hosts are similar.

The pathogenic significance of digenetic parasites in fish is much more pronounced in infections caused by metacercariae than in those caused by adults, because the metacercariae can be encysted in any tissue or organ except cartilages or bones, thereby weakening the host (THATCHER, 1991; EIRAS, 1994; PAVANELLI et al., 1998). In the present study, S. musculosum metacercariae were found in the eyes of $C$. nagelii.

Ramadan (2012) comments that the Diplostomum spathaceum metacercariae in the fish eye leads to severe ocular lesion and results in host mortalities in commercial fish farming. In their study, typical pathological signs of a metacercarial occurrence in the fish eye were included exophthalmia, local hemorrhage and lens cataract. Cloudy eyes were an indication of cataract in fish eyes caused by heavy infestation of metacercariae.

Gil de Pertierra and Ostrowski de Núñez $(1990,1995)$ observed that the parasite life cycle is directly related to the host life cycle, which is related to the characteristics of the external environment in which it lives. The metacercariae found parasitizing the eyes of the fish reinforces these observations, because in that place, the parasite can harm their hosts, thus making them weaker and easier preys. Consequently, the parasite is able to complete its cycle faster. In this study, host weight presented a significant negative correlation

Table 2. Frequency of dominance and mean relative dominance of the metazoan parasites of Cyphocharax nagelii (Steindachner, 1881) in the Peixe River, state of São Paulo, Brazil.

\begin{tabular}{lcc}
\hline \multicolumn{1}{c}{ Parasites } & Dominance frequency & Mean relative dominance \\
\hline Amplexibranchius bryconis & 5.26 & $0.03 \pm 0.003$ \\
Sphincterodiplostomum musculosum & 17.54 & $0.133 \pm 0.0036$ \\
Cosmoxynemoides aguirrei & 0 & $0.055 \pm 0.0033$ \\
Contracaecum sp. & 15.78 & $0.150 \pm 0.0073$ \\
Cacatuocotyle paranaensis & 5.26 & $0.098 \pm 0.0047$ \\
Curvianchoratus hexacleidus & 7.01 & $0.076 \pm 0.0019$ \\
Curvianchoratus singularis & 1.75 & $0.168 \pm 0.0037$ \\
Palombitrema triangulum & 29.82 & $0.279 \pm 0.0064$ \\
\hline
\end{tabular}


Table 3. Dispersion index (DI) and statistical test $(d)$ values of the metazoan parasites of Cyphocharax nagelii (Steindachner, 1881) in the Peixe River, state of São Paulo, Brazil.

\begin{tabular}{lcc}
\hline \multicolumn{1}{c}{ Parasites } & DI & d \\
\hline Amplexibranchius bryconis & 5.87 & 15.07 \\
Sphincterodiplostomum musculosum & 3.52 & 9.32 \\
Cosmoxynemoides aguirrei & 6.88 & 17.22 \\
Contracaecum sp. & 12.51 & 26.9 \\
Cacatuocotyle paranaensis & 8.02 & 19.44 \\
Curvianchoratus hexacleidus & 1.65 & 3.06 \\
Curvianchoratus singularis & 2.87 & 7.39 \\
Palombitrema triangulum & 5.09 & 13.34 \\
\hline
\end{tabular}

with the abundance of $S$. musculosum and the low-weight hosts presented a greater abundance of $S$. musculosum. This can occur due to host feeding difficulty, which is impaired by metacercariae in its eyes, hampering their vision. The metacercariae found may indicate that $C$. nagelii is at an intermediate position in the food chain, since $S$. musculosum is found in the adult stage in birds.

The monogeneans $C$. singularis and $P$. triangulum showed the highest prevalence in this study, while $P$. triangulum showed the highest dominance frequency and relative dominance. This may have occurred because the hosts were collected from a lentic environment (still water). In general, ectoparasites can be found more easily in lentic environments because that is where freeswimming larvae find their host more easily (DOGIEL et al., 1961).

In the present study, all of the parasites presented an aggregated distribution pattern, which is characteristic of parasite systems. The main cause of such distribution in host populations relates to environmental stochastic factors. Among these factors are the environmental changes to physical parameters in time and space, especially differences in host susceptibility to infection, which can occur due to immunological and behavioral differences, as well as genetic factors (ZUBEN, 1997). Parasite population aggregation in a small host population increases the relationship stability, due to regulatory mechanisms such as host mortality, which depends on the parasite density and the decrease in survival and fecundity of parasites caused by intraspecific competition between parasites or immunological reactions of hosts (DOBSON, 1990). According to Zuben (1997), the aggregated distribution pattern works such that it increases the regulation that depends on the density and abundance of hosts and parasites, besides decreasing the interspecific competition level between parasites.

In $C$. nagelii from the Itaipu hydroelectric power station (KOHN et al., 2011) and from the Peixe River (ABDALLAH et al., 2012), Cosmoxynemoides sp. and Contracaecum sp. (ABDALLAH et al., 2012) were recorded. Except for these two species, the other parasites reported in the present study were recorded for the first time in $C$. nagelii.

In conclusion, this study has expanded the geographical distribution and recorded new hosts and infection/infestation sites for some parasite species, thereby increasing the scientific knowledge of biodiversity in a river of great importance for the region.

\section{Acknowledgements}

The authors would like to thank Elisa Pinto de Oliveira for editing the English version. Sponsorships: FAPESP (2010/065645, 2011/22292-8 e 2011/10055-1)

\section{References}

Abdallah VD, Azevedo RK, Carvalho ED, Silva RJ. New hosts and distribution records for nematodes parasites of freshwater fishes form São Paulo State, Brazil. Neotrop Helmintol 2012; 6(1): 43-57.

Bush AO, Holmes JC. Intestinal helminths of lesser scaup ducks: an interactive community. Can J Zool 1986; 64(1): 142-152. http://dx.doi. org/10.1139/z86-023

Bush AO, Aho JM, Kennedy CR. Ecological versus phylogenetic determinants of helminth parasite community richness. Evol Ecol 1990; 4(1): 1-20. http://dx.doi.org/10.1007/BF02270711

Bush AO, Lafferty KD, Lotz JM, Shostak AW. Parasitology meets ecology on its own terms: Margolis et al. revisited. J Parasitol 1997; 83(4): 575-583. PMid:9267395. http://dx.doi.org/10.2307/3284227

Caramaschi EP. Distribuição da ictiofauna de riachos das Bacias do Tietê e do Paranapanema, junto ao divisor de águas (Botucatu, SP) [Dissertação]. São Paulo: Universidade Federal de São Carlos; 1986. PMid:3275190.

Dobson AP. Models of multi-species parasites-host communities. In: Esch G, Kennedy CR, Aho J, editors. Parasite communities: patterns and process. 1990. p. 261-287. http://dx.doi.org/10.1007/978-94009-0837-6_10

Dogiel VA, Petrushevski GK, Polyanski YI. Parasitology of fishes. Leningrad: University Press; 1961. PMid:13723441.

Eiras JC. Elementos de Ictioparasitologia. Porto: Fundação Eng. António de Almeida; 1994.

Gil de Pertierra AA, Ostrowski de Núñez M. Seasonal dynamics and maturation of the cestode Proteocephalus jandia (Woodland, 1933) in the catfish (Rhamdia sapo). Acta Parasitol Pol 1990; 35(4): 305-313.

Gil de Pertierra AA, Ostrowski de Núñez M. Ocurrencia estacional de Acanthostomum gnerii Szidat, 1954 (Acanthostomidae, Acanthostominae) y de dos especies de Derogenidae, Halipeginae, parásitos del bagre sapo, Rhamdia sapo Valenciennes, 1840 (Pisces, Pimelodidae) en Argentina. Rev Bras Biol 1995; 55(2): 305-314

Kohn A, Fernandes BMM. Redescription of Teratotrema dubium Travassos, Artigas e Pereira, 1928 (Callodistomidae: Digenea). Mem Inst Oswaldo Cruz 1987; 82(1): 55-57. http://dx.doi.org/10.1590/S007402761987000100009

Kohn A, Moravec F, Cohen SC, Canzi C, Takemoto RM, Fernandes BMM. Helminths of freshwater fishes in the reservoir of the Hydroelectric Power Station of Itaipu, Paraná, Brazil. Check List 2011; 7(5): 681-690.

Ludwig JA, Reynolds JF. Statistical Ecology: A Primer on Methods and Computing. New York: Wiley-Interscience Publications; 1988.

Magurran AE. Ecological Diversity and It's Measurement. Princeton University Press; 1988. http://dx.doi.org/10.1007/978-94-015-7358-0

Martins ML, Onaka EM. Henneguya garavelli n. sp. and Myxobolus peculiaris n. sp. (Myxozoa: Myxobolidae) in the gills of Cyphocharax nagelli (Osteichthyes: Curimatidae) from Rio do Peixe Reservoir, São 
José do Rio Pardo, São Paulo, Brazil. Vet Parasitol 2006; 137(3-4): 253261. PMid:16540251. http://dx.doi.org/10.1016/j.vetpar.2005.12.023

Novaes JLC. Estudo comparativo da pesca artesanal em dois grandes reservatórios do Alto Paraná: Barra Bonita (Rio Tietê) e Jurumirim (Rio Paranapanema) [Dissertação]. São Paulo: Universidade Estadual Paulista; 2008.

Pavanelli GC, Eiras JC, Takemoto RM. Doenças de peixes: Profilaxia, diagnóstico e tratamento. Maringá: EdUEM; 1998.

Pavanelli GC, Takemoto RM, Machado, PM, Lizama MAP, Tanaka LK, Guidelli GM, et al. Ictioparasitologia [online]. 2000 [cited 2013 jul]. Available from: http://www.peld.uem.br/Relat2000/2_2_ CompBioticoIctioparas.PDF

Pielou EC. Mathematical Ecology. New York: John Wiley \& Sons; 1977. PMid:269129.
Ramadan RAM. Effect and Seasonal dynamics of Diplostomum spathaceum (eye fluke) on Oreochromis nilotcus at Abbassa Fish Farm, Egypt. Egypt J Aquaculture 2012; 2(1):105-113.

Rohde K, Hayward C, Heap M. Aspects of the ecology of metazoan ectoparasites of marine fishes. Int J Parasitol 1995; 25(8): 945-970. http:// dx.doi.org/10.1016/0020-7519(95)00015-T

Thatcher VE. Amazon fish parasites. Amazoniana 1991; 11(3-4): 263-572.

Vari RP. Systematics of the Neotropical characiform genus Cyphocharax Fowler (Pisces, Ostariophysi). Smithson. Contrib. Zool; 1992.

Zar JH. Biostatistical Analysis. New Jersey: Prentice-Hall Inc.; 1999.

Zuben CJV. Implicaçóes da agregação espacial de parasitas para a dinâmica populacional na interação hospedeiro-parasita. Rev Saúde Pública 1997; 31(5): 523-530. http://dx.doi.org/10.1590/S003489101997000600014 